\title{
Series of problems in Arabic algebra: The example of Alī al-Sulamī
}

\author{
Jeffrey Oaks ${ }^{\mathrm{a}}$ \\ Department of Mathematics and Computer Science, University of Indianapolis, Indianapolis, IN, USA
}

\begin{abstract}
In his introductory book on algebra 'Alī al-Sulamī (10th c.) pays careful attention to the arrangement of his 78 worked-out problems, balancing his borrowings with his overall structure. His collection is put into context by comparing it with the problems in the books of three other early Arabic algebraists. It is shown that unlike al-Khwārizmī and Abū Kāmil, al-Sulamī orders his problems carefully. He gives a global ordering based on equation type that is an inversion of the local ordering of his predecessors, and he exhibits a local ordering that is a consequence of his appropriation of diverse problem types within his collection.
\end{abstract}

\section{Introduction}

There is a many-layered richness in the collections of worked-out problems presented in Arabic arithmetic books, of which collections in books devoted to algebra form a well-defined subclass. Four particular early treatises on algebra offer an opportunity for inquiry into the ways that mathematicians borrowed from earlier algebra books and from other realms of arithmetic on the one hand, and the ways they introduced innovations on the other. These are the books of al-Khwārizmī (early 9th c.), Abū Kāmil (late 9th c.), 'Alī al-Sulamī (10th c. ${ }^{1}$ ), and al-Karajī (his al-Fakhrī, early 11 th c.).

In this article I will focus on 'Alī al-Sulamī's Sufficient Introduction on Calculation by Algebra and What One Can Learn from its Examples, and bring in the other three works for comparison and historical context. Only one manuscript of al-Sulamì's book is known: MS Vatican, Sbath 5. I have chosen it because it has received almost no attention from modern historians, ${ }^{2}$ and because the author gives a structure to his problems that is not found in other books. Three questions I will be keeping in mind are: First, what can we say about the order of the problems? Second, what are the sources from which the author borrowed? And third, how does al-Sulamī's book compare with the books of the other algebraists?

\footnotetext{
${ }^{a}$ e-mail: oaks@uindy.edu. I thank Alain Bernard and Marc Moyon for their helpful comments on an earlier version of this article.

${ }^{1}$ Rosenfeld and Ihsanoğlu ([11], p. 99) date his book to the tenth century, but Rashed ([10], p. 98) claims that al-Sulamī was a successor of al-Karajī. Al-Sulamī borrowed elements from Abū Kāmil, so he cannot have written earlier than the late ninth century. But I see no evidence that he knew the work of al-Karajī, nor that al-Karajī knew of his book. The only extant manuscript was copied in $1211 \mathrm{CE}$.

2 The only mention of it I have found in the secondary literature is a brief account of the higher degree equations in [10], pp. 98-9.

This is an Open Access article distributed under the terms of the Creative Commons Attribution License 4.0, which permits unrestricted use, distribution, and reproduction in any medium, provided the original work is properly cited.
} 
To make sense of al-Sulamī's seriality it will be necessary to first cover some preliminaries, beginning with a description of the method of Arabic algebra. This is followed by an outline of the contents and organization of the four algebra books and a brief overview of problem types. Then I describe the 78 problems in al-Sulamī's book, and I conclude with a general assessment. Some of al-Sulamì's problems are translated in an appendix.

We will see that al-Sulamī pays much closer attention to the organization of his treatise, and especially to the seriality of his problems, than did al-Khwārizmī or Abū Kāmil. There is a local ordering to the first six problems in al-Khwārizmī's and Abū Kāmil's books based on the six canonical equations, and this idea is behind the global ordering of al-Sulamì's collection. Also, with a wider variety of problem types in his collection, al-Sulamī gives his problems a deliberate, local seriality based on these types. And contrary to al-Khwārizmī and Abū Kāmil, al-Sulamī shows little of what I call historical seriality, which results from the direct borrowing of a sequence of problems from another source.

The books of al-Khwārizmī, Abū Kāmil, and al-Karajī show an overall structure that is designed for practical instruction, but they also include many elements of theoretical interest. Al-Sulamī's book follows this same structure, but apparently the only part that might be called "theoretical" is the chapter on higher degree equations at the end. His book contains no proofs, for example. This suggests that the main purpose of al-Sulamī's treatise was to instruct students in how to solve problems by algebra. The analysis of the organization of al-Sulamì's problems below will further support this assessment. Unfortunately we possess little information on mathematics education for this period other than what we can glean from textbooks like this one.

\section{Problem-solving by algebra}

A review of the basic features of Arabic algebra will be expedient for an analysis of al-Sulamī's problems. For one, it is necessary to distinguish between enunciations of problems and algebraic equations in order to make sense of the overall organization of his problems. Also, one must understand what distinguishes the method of algebra from other problem-solving techniques, since some problems in all four books receive non-algebraic solutions.

Arabic algebra was a numerical method of problem-solving that was practiced alongside other methods such as the rule of three, single false position, double false position, "arithmetical reasoning", etc. In the other methods operations are performed on known quantities to arrive at the solution. In an algebraic solution an unknown number is named using the special terms, or "species" ( nau $^{c}$ ), designating the powers of the unknown. Calculations are then performed on these names, and an equation is set up and solved. These names are:

shay' ("thing") or jidhr ("root"), corresponding to our $x$.

māl ( sum of money), corresponding to our $x^{2}$.

$k a^{c} b$ ("cube"), corresponding to our $x^{3}$.

$m \bar{a} l m \bar{a} l$, corresponding to our $x^{4}$, etc..

Units were often counted in dirhams, a silver coin, as "units", or "in number". The plural of $m \bar{a} l$ is $a m w \bar{a} l$, but I will write it with the English suffix: $m \bar{a} l$ s. The word $m \bar{a} l$ was also commonly used in Arabic arithmetic to mean an amount of money or a generic quantity. In arithmetic $m \bar{a} l$ operates as a common noun, while in algebra it is the name of the power. We will see the word used in this arithmetical way in the enunciations of many problems. ${ }^{3}$

Once an unknown is named, the operations called for in the enunciation are worked out to form an equation. This is then simplified and solved. Simplified equations of degree 1 and 2 are classified

\footnotetext{
${ }^{3}$ See [9] for more on the meanings of $m a \bar{l} l$.
} 
into six types. This is because their solutions follow an algorithm on the "numbers" (coefficients) of the terms, and these cannot be negative or zero. Three of these equations have two terms, which al-Sulami calls "simple" (mufrad), and the other three have three terms, which he calls "connected" (muqatarna). ${ }^{4}$ He gives the equations in this order in the beginning of his book: ${ }^{5}$

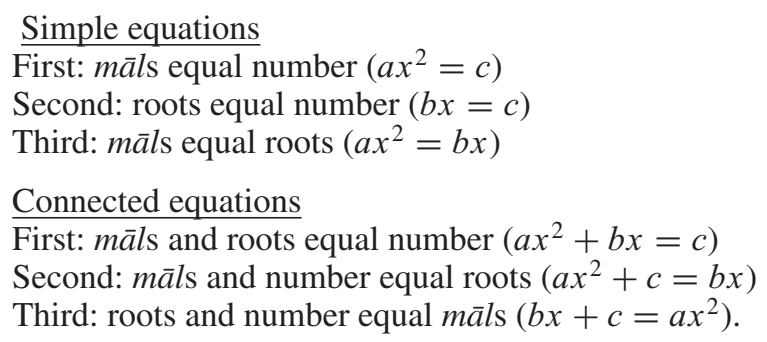

This is different from al-Khwārizmī and Abū Kāmil, who give the first three in this order: $a x^{2}=b x$, $a x^{2}=c$, then $b x=c$. Later, al-Karaji will give this order for the first three: $b x=c, a x^{2}=b x, a x^{2}=c$.

As an example, here is al-Sulamî̀s problem (I.6) (I put the corresponding modern symbols in brackets): ${ }^{6}$

\section{[Enunciation]}

So if [someone] said, ten: you divided it into two parts. You multiplied each one of them by itself, then you cast away one of the two amounts from the other, leaving forty.

\section{[Solution]}

So make one of the parts a thing $[x]$ and the other ten less a thing $[10-x]$. Then multiply each one of the parts by itself. A thing by a thing is a $m \bar{a} l\left[x^{2}\right]$, and ten less a thing by ten less a thing is a hundred and a $m \bar{a} l$ less twenty things $\left[100+x^{2}-20 x\right]$. So cast away a $m \bar{a} l$ by a $m \bar{a} l$, leaving a hundred less twenty things equal forty dirhams $[100-20 x=40]$.

Restore the hundred by the twenty and add it to the forty, so it becomes: a hundred equals forty and twenty things $[100=40+20 x]$. Cast away the forty by the forty, leaving: sixty equals twenty things $[60=20 x]$. So the thing is three, which is one of the parts.

The distinction between an equation and the enunciation of a problem is crucial for understanding alSulamî's seriality. This is most evident in their locations in the problem: the enunciation is the question being asked, and the equations appear in the solution. In this case the enunciation is to find the parts of ten given a certain condition, and the equation is first set up as "a hundred less twenty things equal forty dirhams" $(100-20 x=40)$. There are also linguistic differences. Equations are stated in terms of the algebraic names ("things", "māls", etc.), while the enunciations of problems are expressed with common nouns (here "parts"). Another difference is that equations express the equality of two static amounts with no operations present, using the unusual verb 'adala, while enunciations are usually stated with operations and a specified outcome. In this problem the equation is simplified to "sixty equals twenty things" $(60=20 x)$, which is the second simple type in al-Sulamî's list.

I should say something about the words our Arabic authors used for "problems" and "equations", since it is not as simple as it is in English. Arabic algebra books written in the ninth century show no specific word for "equation". Instead, when al-Khwārizmī, Abū Kāmil, and others wish to call them by

\footnotetext{
4 Al-Khwārizmī and Abū Kāmil have no words for "simple" or "connected". Al-Karajī uses both terms, though he also calls the "connected" equations "composite" (murakkab) ([12], pp. 148-9).

5 f. 5 a. $7 \mathrm{ff}$.

6 f. 40 b. 7 .
} 
some word, they use mas'ala ("problem", pl. mas $\vec{a}^{3} i l$ ). This was the word in general use for any kind of question, whether it be in geometry, arithmetic, or another field entirely. It was Qustā ibn Lūqā who in the latter ninth century introduced the Arabic word that specifically means algebraic "equation", in his translation of Diophantus' Arithmetica. This is $m u^{`} \bar{a} d a l a$ (pl. $m u^{c} \bar{a} d a l \bar{a} t$ ) which derives from the verb 'adala used to equate the two sides of an equation. ${ }^{7}$ Sinān Ibn al-Fath (first half of 10th c.) is earliest Arabic algebraist we know to use the term himself. While most later authors continued to call the six equations by the traditional designation $\operatorname{mas} \vec{a} i l$, they frequently referred to equations in other parts of their books as $m u^{c} \bar{a} d a l \bar{a} t .^{8}$

Problems were often called mas'ala, but also sometimes amthila (sing. mithāl), "examples". 'Alī al-Sulamī calls equations masă $\bar{a}^{\supset} l$, and he calls problems both masă $i l$ and amthila.

\section{The structure of early Arabic algebra books}

The position occupied by a series of problems within the logical structure of a work is of course important for any study of the problems. In the case of early Arabic algebra this "synchronic" relationship should be considered in conjunction with the "diachronic" relationship that the problems, and indeed the whole book, has with similar texts written in the previous and following centuries. For this reason I present below the structures of the four books together with some comments about their contents and influences.

First, though, it will be helpful to show some of the common ways that manuscripts divide the different parts of the treatises, even if it oversimplifies a complex topic. A single work is often called a "book" (kitāb, pl. kutub). Sometimes larger works are comprised of more than one kitāb, and these "books" can often be regarded as separate treatises. A kitāb is often divided into "chapters" (abwāb, sing. $b \bar{a} b$ ) or "sections" (fuṣull, sing. faṣl). In some books a fașl is divided into abwāb, and in some others a $b \bar{a} b$ is divided into fușūl. As we shall see below, 'Alī al-Sulamī divided his abwāb into fuṣūl,

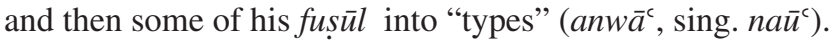

The earliest extant comprehensive treatise on algebra in Arabic is the famous Book of Algebra by al-Khwārizmī, written sometime 813-833 CE [4]. Below is a list of its contents, with chapter headings from the manuscripts. I have numbered the chapters I.1 to I.7 and II for easy reference.

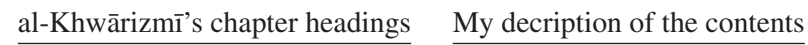

[I.1] $\overline{\text { General introduction (p. 939 })}$

Names of the powers (97)

The six equations with examples and solutions (97)

Proofs for the three composite equations (109)

$B \bar{a} b$ on mutiplication [I.2] Multiplication of binomials (123)

$B \bar{a} b$ on adding and subtracting [I.3]

Adding and subtracting diminished polynomials (131)

Operations with roots (131)

Proofs for the subtraction of diminished polynomials (137)

$B \bar{a} b$ on the six problems [I.4] Six problems, one for each type of equation (145)

$B \bar{a} b$ on various problems [I.5] A collection of $33^{10}$ more problems (157)

$B \bar{a} b$ on business transactions [I.6] The rule of three, with three problems (197)

$B \bar{a} b$ on mensuration [I.7] Introduction to practical geometry (203)

Kitab/bāb on wills [II] This book is divided into nine chapters (abwāb) (233-331)

\footnotetext{
7 The fact that medieval equations were not conceived of the same way as modern equations does not mean we should choose a different word for them. For another example, Euclid's arithmos is radically different from the modern "number", but we should still translate it as "number" and read it with this difference in mind.

8 See [6], Sect. 5.2, for a full discussion.

${ }^{9}$ Page numbers are from Rashed's edition $[4,5]$.

${ }^{10}$ Problem (7) in the Oxford manuscript was probably added later, so Rashed's edition shows 34 problems.
} 
There is some variation in the chapter headings in the manuscripts. Rashed's critical edition primarily makes use of four Arabic manuscripts ${ }^{11}$ and Gerard of Cremona's twelfth century Latin translation. Among the Arabic manuscripts, the Medina MS copied in 1222 routinely leaves off the word $b \bar{a} b$, and the Berlin MS shows a blank space for the chapter headings that were intended to be filled in later with red ink. The other two Arabic manuscripts and Gerard's Latin translation generally include the full heading. The chapter on wills is called a kitāb in the Oxford MS, a $b \bar{a} b$ in the Medina MS copied in 1767, and it is given no heading in the other two Arabic manuscripts.

Regardless which manuscripts reflect al-Khwārizmī's original, his use of the word $b \bar{a} b$ ("chapter") was not strict. At one point in I.7 he refers to his " $b \bar{a} b$ on triangles", which in fact is a single rule in the same chapter and without a heading in any manuscript. ${ }^{12}$

The six problems in I.4 are introduced as "the first of the six", "the second problem", "the third problem", down to "the sixth problem". They are given to illustrate in order the six canonical equations. For example, the enunciation of the sixth problem is "A $m \bar{a} l:{ }^{13}$ you multiplied its third by its fourth so it brought back the $m \bar{a} l$ with twenty-four dirhams added." 14 The simplified equation in the solution is "half a sixth of a $m \bar{a} l^{15}$ equal a thing and twenty-four dirhams" (we would write this in moden notation as $\left.\frac{1}{2} x^{2}=x+24\right)$. This equation is of the sixth type in al-Khwārizmī's list.

The 33 various problems in chapter I.5 do not appear to be given any particular order, except that similar problems are sometimes grouped together. Only two thirds of these problems are solved by algebra, that is, by naming an unknown and setting up and solving an equation. The remaining eleven problems are worked out by "arithmetical reasoning". ${ }^{16}$ In this method the author merely reasons with the given numbers in the problem to obtain the answer.

The following chapter I.6 explains the rule of three, another method distinct from algebra, with three sample problems. In the fifteen pages of rules and problems in chapter I.7, on mensuration, only two problems are solved by algebra. And last, the book on wills contains sixty problems, most of which are soved by algebra.

Abū Kāmil wrote his own Book on Algebra in the late ninth century in Egypt [1,2]. He explicitly cites al-Khwārizmī, and he borrows many examples and problems from al-Khwārizm̄̄'s book. The single extant Arabic manuscript of Abū Kāmil's book does not use the words kitāb and $b \bar{a} b$ at the start of new books or chapters. Rather, it begins each major new part, or book, with a new page and the phrase "In the name of God, merciful and compassionate". I indicate these points in the list below with "[Kitāb]".

\begin{tabular}{|c|c|}
\hline \multirow{8}{*}{ Kitāb I] } & My description of Abū Kāmil's contents \\
\hline & General introduction (p. $2 / 243^{17}$ ) \\
\hline & Names of the powers $(4 / 247)$ \\
\hline & The six equations with examples, solutions, and proofs $(5 / 247)$ \\
\hline & Multiplication of monomials and binomials (23/281) \\
\hline & Operations with roots $(33 / 299)$ \\
\hline & Six problems, one for each type of equation $(42 / 321)$ \\
\hline & 68 other problems $(49 / 335)$ \\
\hline$[$ Kitāb II] & On the pentagon and decagon (134/523) \\
\hline \multirow[t]{4}{*}{ Kitāb III] } & 38 abstract indeterminate problems $(157 / 579)$ \\
\hline & 5 indeterminate problems posed in terms of commerce $(189 / 654)$ \\
\hline & 41 assorted problems, mostly about financial dealings (199/675) \\
\hline & Summing geometric progressions (216-221/719-729) \\
\hline
\end{tabular}

\footnotetext{
11 A fifth manuscript, in Tehran, only includes the chapter on mensuration.

12 [4], p. 215.2.

13 Here the word $m \bar{a} l$ takes its meaning in arithmetic as a quantity or number, and not as the name of the second power in algebra.

14 [4], p. 155.6 .

15 Here the word $m \bar{a} l$ takes its algebraic meaning.

16 See $[8,9]$ for a description of this method.

17 Page numbers are from [1] and [2].
} 


\section{SHS Web of Conferences}

These three "books" could stand as independent treatises, like al-Khwārizmī's chapter on mensuration or his "book" on wills. The structure of book I is modeled on al-Khwārizmī's chapters I.1 through I.5. In fact, the problems in al-Khwārizmî's chapters I.4 and I.5 are of the same types as the six and 68 subsequent problems in Abū Kāmil's book I (I discuss problem types below in Sect. 4). After book I there is little in common between al-Khwārizmī and Abū Kāmil. Abū Kāmil does not solve problems by the rule of three like al-Khwärizmī, and the chapters/books on mensuration/geometry in the two treatises are entirely unrelated.

Four of Abū Kāmil's "68 other problems" are solved by "arithmetical reasoning", and one of these receives an algebraic solution in the margin. ${ }^{18}$ Further, several of the problems in book III are also solved by this non-algebraic method. ${ }^{19}$

'Alī al-Sulamī shows borrowings from both al-Khwārizmī and Abū Kāmil. The unique manuscript of this treatise is meticulously organized into chapters $(b \bar{a} b)$ and sections $(f a s ̣ l)$ which are even numbered "first", "second", etc. in the middle two chapters:

\section{'Alī al-Sulamī's chapter headings}

[Introduction] (f. 2b)

First $b \bar{a} b$, on explaining the six problems and their ordering ${ }^{20}$ (f. $5 \mathrm{a}$ )

Fașl [on the connected problems] (f. 6a)

Faṣl on appendices (lawāhiq) [i.e.,higherpowers“appended”tothingsandmāls] (f. 8b)

Second $b \bar{a} b$, on decreasing and composing, which is adding roots and subtracting them and multiplying ${ }^{21}$ them and dividing them and what follows them (f. 14a)

First fasl, on the multiplication of simple ${ }^{22}$ [square] roots, cube [roots], and roots of roots (f. 14b)

Second fasl, this is the chapter on division, which is quantities in species $^{23}$ (f. 19a)

Fourth fasl, on adding [square] roots and cube [roots] (f. 27b)

Fifth fașl, on subtracting [square] roots and cube [roots] (f. 33b)

Sixth fașl, this chapter is on adding and subtracting collected species ${ }^{24}$ (f. $35 \mathrm{~b}$ )

Third $b \bar{a} b$, on examples that reduce to the six problems and the rules for working them out, in sections (fusūul). (f. 38a)

First fasl, on examples that lead to things equal number ${ }^{25}$ (f. 38a)

Second fasl of this chapter, on problems that lead to $m \bar{a} l s$ equal roots (f. $58 \mathrm{~b}$ )

Third $f a s ̧ l$, on problems that lead to $m \bar{a} l$ s equal number (f. 63a)

Fourth fașl, on problems that lead to $m \bar{a} l \mathrm{l}$ and roots equal number (f. 66b)

Fifth fas $l$, on problems that lead to $m \bar{a} l s$ and number equal roots (f. 71a)

Sixth faṣl, on problems that lead to roots and number equals a $m \bar{a} l$ (f. 83a)

Fourth $b \bar{a} b$, on cubes and $m \bar{a} l \mathrm{~s} m \bar{a} l \mathrm{l}$ (ff. 86a-98a)

Faṣl [on connected higher degree equations ${ }^{26}$ ] (f. 89b)

Fașl [on connected higher degree equations ${ }^{27}$ ] (f. 90b)

\footnotetext{
18 The two solutions are translated in [8], Sect. 3.

19 The problems numbered (44), (51), (52), (53), (58), and (59) in [2], pp. 683-709.

${ }^{20}$ Unlike the other three authors, al-Sulamī does not include any proofs in his book.

21 This word was miscopied as $s-z$.

22 I.e., single; monomial.

23 I.e. algebraic monomials.

24 This is followed by a word I cannot make out: muh-t-il-q?

25 The MS mistakenly has "things equal roots".

26 Here he solves those in which the powers are consecutive, like $x^{4}+x^{3}=6 x^{2}$.

${ }^{27}$ Here he solves those in which the powers are proportional, like $x^{6}+8 x^{3}=128$.
} 
Fașl [special solvable cases of four term equations.] (f. 92b)

Fașl [operating on higher powers and their roots.] (f. 95a).

The first three chapters are organized like al-Khwārizmī's I.1 to I.5 and Abū Kāmil's book I, showing the rules of algebra followed by a collection of problems. It is worth noting already that al-Sulami divides chapter 3 into six sections, one for each type of equation. Chapter 4 gives a classification and discussion of higher degree equations. This chapter contains no worked-out problems, and corresponds to nothing in al-Khwārizmī or Abū Kāmil.

The last algebra book in our group is al-Karajī's Book of al-Fakhrī on the Art of Algebra, written 1011/12 CE [12]. Although Saidan consulted six of the nine known manuscripts for his edition of the text, he does not give a critical apparatus showing variations. In the edition different sections are introduced with brief headings like "on the extraction of roots" and "on subtraction". Only three instances out of at least ten show the word $b \bar{a} b$ (other headings might have been intended as fușu $l$ ). Al-Karajī's worked-out problems are organized into five "categories" (tabaqāt, sing. tabaqa), announced by "first tabaqa", "second tabaqa", etc.. I only list some of the many headings from this book:

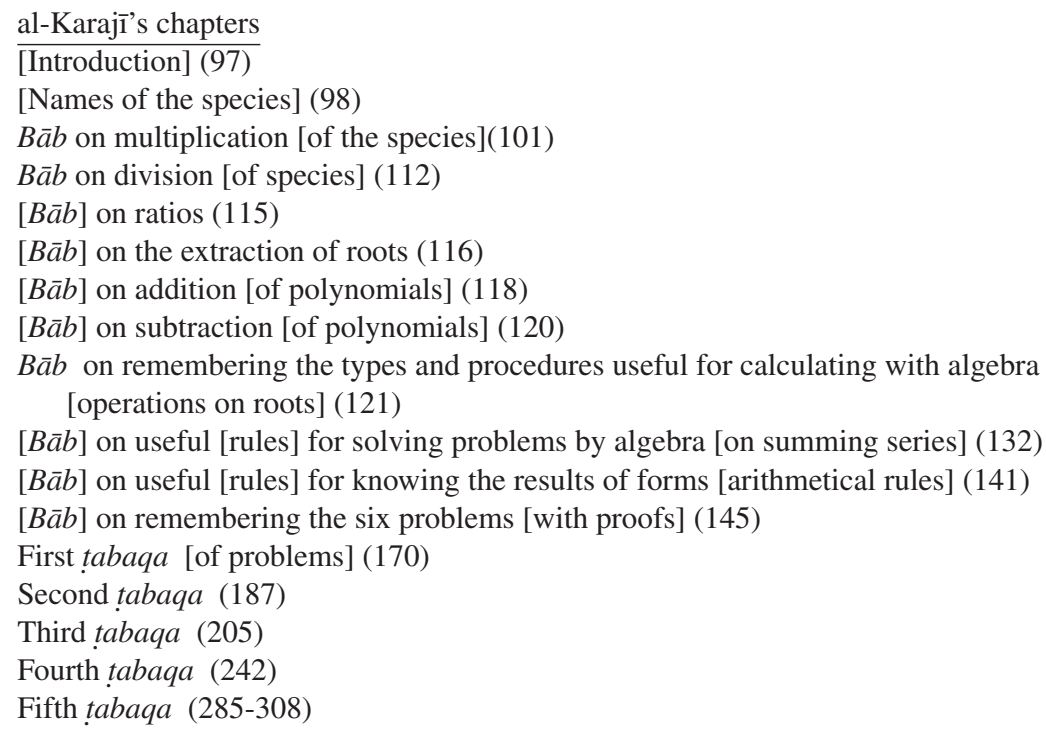

Al-Karajī was influenced mainly by Diophantus and Abū Kāmil. A total of 102 of his 255 problems are taken from the Arithmetica, while many others are from Abū Kāmil's Algebra. Al-Karajī also knew al-Khwārizmī's book, but he does not show any influence from 'Alī al-Sulamī.

There is a core structure that is common to all four of these treatises on algebra. This is alKhwarizmī’s chapters I.1 to I.5, Abū Kāmil's book I, al-Sulamī's chapters 1 to 3, and all of al-Karajī’s book. What these parts have in common is that they introduce the powers, the six equations, and operations on roots and polynomials, after which they pass to a collection of problems. I call this core the "algebra proper". ${ }^{28}$ This structure is also found in later algebra books, like those of Ibn Badr (13th century?) and Ibn al-Bannā' (late 13 th century). ${ }^{29}$

\footnotetext{
28 I borrowed this phrase from Adel Anbouba, who referred to this core as "l'algèbre proprement dite" in [3].

29 Both Ibn Badr's Brief Book on Algebra and Ibn al-Bannā’s Book of Algebra are edited in [12].
} 


\section{SHS Web of Conferences}

\section{Problem types}

A discussion of the types of problems solved in Arabic arithmetic is required in order to properly analyse al-Sulamî's problems, both so we can understand the adjustments he made to the works of his predecessors, and so we can understand his local seriality.

Problems in Arabic arithmetic, including algebra, can usually be classified according to type. Many of al-Khwārizmì's and Abū Kāmil's problems fall into one of two main types, which I call type [M] and type [10]. Type [M] problems begin "A $m \bar{a} l$ ", followed by some condition on the unknown $m \bar{a} l$. Here the word $m \bar{a} l$ does not take its algebraic meaning, but intends a generic amount. ${ }^{30} \mathrm{Al}$-Khwārizmì's problem (T4) is an example: "A $m \bar{a} l$ : you multiplied its third and a dirham by its fourth and a dirham to get twenty." "31. Type [10] problems begin "Ten, you divided it into two parts", with some condition on the parts. An example is al-Khwārizmî's problem (T5): "Ten: you divided it into two parts, and you multiplied each part by itself and you added them, so it gave fifty-eight dirhams". ${ }^{32}$ Type [M] problems are very common in Arabic arithmetic for algebra as well as other methods like single false position and double false position, though certain sub-types are typically solved by algebra while others are typically solved by other methods. Type [10] problems are most commonly solved by algebra, and sometimes a number other than 10 is used.

Almost all of the problems in al-Khwārizmī's and Abū Kāmil's "algebra proper" are of type [M] or type [10]. The exceptions are some problems that ask for a certain amount of money to be divided among some men. ${ }^{33}$

Mercantile and other practical problems are found in subsequent parts of al-Khwārizmī's and Abū Kāmil's treatises. In his chapter on business transactions al-Khwārizmī applies the rule of three to solve three problems: "ten for six, how many will you get for four?", "ten for eight, what is the price of four?", ${ }^{44}$ and "a worker is hired for ten dirhams per month, and has worked for six days, how much should he get?"35. As mentioned above, al-Khwārizmī also solves two mensuration problems by algebra, and he solves sixty inheritance problems, most by algebra, in his book on wills.

Abū Kāmil solves twenty geometry problems in his On the Pentagon and Decagon, all but problems (6) and (11) with algebra. His first 38 indeterminate problems are posed as type [M] or type [10] and show no direct influence from Diophantus. Most are solved by algebra, while others are worked by "arithmetical reasoning". The remaining problems in this chapter are stated in practical terms. Some concern a number of men who want to buy a horse, others on the distribution of booty among some soldiers, others on how long it takes one postman to catch up with another, others on measures of grain, etc.. Many of these, too, are solved by "arithmetical reasoning".

'Alī al-Sulamī and al-Karajī also solve many type [M] and type [10] problems. In addition, they incorporate many practical problems in their "algebra proper" that in al-Khwārizmī and Abū Kāmil would have been relegated to a later part of the treatise. One example is al-Sulamī's problem (I.12): "[A worker] is paid per month ten dirhams and some unknown thing. He worked three days and took the unknown." ${ }^{36} \mathrm{He}$ solves eleven such problems in a row, each a variation on this one. Another type is problem (IV.7): "Troops collect some booty. The first [soldier gets] two dirhams. Then each succeeding one gets three more than the one before, so that the total booty is a hundred twenty-six dirhams."

\footnotetext{
30 See [9], [6].

31 [4], p. 151.

32 [4], p. 153.

33 Al-Khwārizmī: problems (24) and (28). Abū Kāmil: problems (4) through (9).

34 Translations adapted from [5], p. 198.

35 Translation from [5], p. 200.

36 f. 42 b. 4 .
} 
The question is to find the number of soldiers. About a third, or 26, of 'Alī al-Sulamī's problems solved by algebra are of such practical types, while the other two thirds, or 50, are type [M] or type [10].

'Alī al-Sulamī and al-Karajī also solve many abstract indeterminate problems. 'Alī al-Sulamī's problems come from the same tradition as Abū Kāmil's type [M] indeterminate problems, but are not borrowed from that book. Al-Karajī solves fifteen type $[\mathrm{M}]$ indeterminate problems from this same tradition, some borrowed from Abū Kāmil, and he also includes the 102 problems directly translated from Diophantus' Arithmetica. The two classes of problems are easily distinguishable by their wording.

\section{Organization and seriality of al-Sulamī's problems}

Seriality comes in different kinds. For instance, one can distinguish between historical and deliberate seriality. In historical seriality an author copies a sequence of problems from another source. An example is al-Karajī's problems IV.21 to IV.23, which are borrowed in order from Abū Kāmil's problems (57) to (59). Most often, though, historical borrowing is more casual, like we see in al-Karajī's indeterminate problems II.22 through II.26. These are slightly modified from Abū Kāmil's problems (1), (2), (3), (5), and (6). In deliberate seriality the author chooses an ordering for a particular purpose. For example, the first six of al-Khwārizmī's problems are designed to illustrate in order the solutions to the six canonical equations. Abū Kāmil's first six problems serve the same purpose, with some borrowing from al-Khwārizmī.

We can also distinguish between local and global seriality. Al-Khwārizmī's six problems just mentioned is an example of local seriality, since these problems are part of a larger collection of 39 problems. 'Alī al-Sulamī's collection of problems shows global seriality, or what might be better called global ordering. He divides his 78 problems into six groups following the same criterion as al-Khwārizmī's first six problems.

These two ways of considering seriality, historical/deliberate and local/global, are all present in 'Alī al-Sulamī's problems. But before turning to his collection I should say a few words about the other algebraists. The problems that follow the first six in al-Khwārizmī and Abū Kāmil do not show any overall organizational structure. Problems seem to be taken or modified from other sources without much thought about their ordering, and are mixed with what are probably new problems. About all we can say about the order is that problems of the same type tend to be grouped together, and within these groups, especially within subgroups, they tend to progress from simplest to most complex.

Al-Karaji forgoes the first six problems illustrating the six equations. His problems are divided into five "categories", and there is too much to say about the ordering of his problems to begin to describe it here. I will only remark that like 'Alī al-Sulamī, he pays more attention to seriality than al-Khwārizmī and Abū Kāmil.

As we shall see, 'Alī al-Sulamī gives his problems a global ordering that could not work for the other three algebraists. And as I noted in [8], al-Khwārizmī especially, and Abū Kāmil and al-Karajī also, do not solve all of their problems in the "algebra proper" by algebra. Some problems are solved by a related technique that I call "arithmetical reasoning". But with two accountable exceptions all of 'Alī al-Sulamī’s solutions are algebraic. Further, like al-Khwārizmī, 'Alī al-Sulamī gives only one solution for each problem (with one accountable exception). Abū Kāmil and al-Karajī, on the other hand, often give two or more different algebraic solutions to a single enunciation.

With a single, algebraic solution to each problem 'Alī al-Sulamī is able to classify his problems by the type of simplified equation that appears in the solution. This allows him to divide his collection into six sections, one for each equation type. This is a global version of al-Khwārizmī's and Abū Kāmil's local ordering of their first six problems.

In Abū Kāmil determinate type [M] and type [10] problems are placed in the "algebra proper", while indeterminate problems and those framed in practical terms are presented in a later book. 
Al-Sulamī does not solve problems outside his "algebra proper", and we find these other problems types incorporated within his main collection.

It is also noteworthy that al-Sulamī switches the order of the equations that he gave in the first chapter. The simple equations are now put in this order: $b x=c, a x^{2}=b x, a x^{2}=c,{ }^{37}$ so that the section on first degree equations is now first. The kinds of problems whose algebraic solutions lead to such equations are precisely those that were commonly solved by other, arithmetical methods like single false position and the rule of three. Al-Khwārizmī, recall, gave a separate chapter after his "algebra proper" on "business translations", where he explains the rule of three with sample problems. Now alSulamī incorporates this method and two sample problems within his main collection, at the end of his chapter on equations of the type $b x=c$. So again, what was a global division in al-Khwārizmī becomes integrated into al-Sulamī's problems.

Everything covered so far has been presented as a means to better understand the descriptions of al-Sulamī's problems in section 6 below. This includes not just the fundamentals of Arabic algebra, but also, building on that, the global/local interchanges from al-Khwārizmī and Abū Kāmil to al-Sulamī. Certain problem-types separated globally in the earlier authors become local distinctions in al-Sulamī, and the local ordering of the first six problems in al-Khwārizmī and Abū Kāmil become the global ordering of al-Sulamî's collection.

\section{Survey of the problems}

As we saw in Sect. 3, al-Sulamī's chapter of worked-out problems begins: "Third chapter (bāb). On examples (amthila) that reduce to the six problems (mas $\left.\vec{a}^{3} i l\right)$ and the rules for working them out, ${ }^{38}$ in sections. First section: on examples that lead to "things equal number"." 39 He begins immediately with the problems. These are not numbered in the manuscript, so I number them by section: (I.1) through (I.37) for the problems in the first section, (II.1) to (II.9) for problems in the second section, etc..

Problems (I.1) to (I.4)

Type [M] problems that ask for a $m \bar{a} l$ to which is added or subtracted fractional parts of itself (problems (I.1) to (I.3)), or on which repeated operations are performed (problem (I.4)). These subclasses are not found in al-Khwārizmī or Abū Kāmil, but are common in arithmetic books where they typically receive solutions by single or double false position or working backwards. Problem (I.1) is translated in the Appendix.

Problems (I.5) to (I.8)

Type [10] problems. Al-Khwārizmī's and Abū Kāmil's type [10] problems are generally more complex, yielding three-term quadratic equations. 'Alī al-Sulamī's problems in this section are naturally relatively simple. Problem (I.6) is translated above in Sect. 2.

Problem (I.9)

A type $[\mathrm{M}]$ problem that asks for two different $m \bar{a} l$ s whose difference is two and whose quotient is ten.

Problems (I.10) and (I.11)

Two problems on buying and selling.

Problems (I.12) to (I.22), announced in larger letters with "On calculating a wage (ajr)". This group of problems all deal with a worker hired by the month. The enunciation to problem (I.12) is given above in Sect. 4. Al-Khwārizmī solves a similar problem by the

\footnotetext{
37 This is the same order that al-Karajī would later give.

38 Here we see al-Sulamī calling problems "examples" and equations "problems".

39 f. 38a.7. The copyist mistakenly wrote "roots" instead of "number".
} 
rule of three in his chapter on "business transactions" ( $\left.m u^{\complement} \bar{a} m a l \bar{a} t\right)$, also translated above in Sect. 4. Al-Sulamī's problems (I.19) to (I.22) are similar to three problems in Abū Kāmil's third book, numbered by Rashed (I.54) to (I.56). ${ }^{40}$ Al-Karajī's I.21 and I.22 are also of this type.

Problem (I.23), announced as "Another type, on a payment (sarf)". This is another mercantile question.

Problems (I.24) and (I.25), announced as "Another type, on reservoirs (ahwād)". These problems ask how long it will take two or three rivers flowing at different rates to fill a reservoir.

Problems (I.26) to (I.35), announced by "another type".

These are all type $[\mathrm{M}]$ problems. All but problem (I.33) are indeterminate, and belong to the same tradition from which Abū Kāmil drew. None of 'Alī al-Sulamī's problems are taken from that book. Problem (I.33) is the same as al-Khwārizmī's problem (33). Although worded differently, the two solutions unfold the same way.

Problems (I.36) and (I.37), announced as "Another type, on encounters (talāqū)".

In these problems two or three men want to buy a horse.

Before moving on to the second type of equation 'Alī al-Sulamī gives another subsection, "Another type, on calculating business transactions". Like al-Khwārizmī's chapter with the same name (mu'ämalāt), 'Alī al-Sulamī introduces proportion and the rule of three.

Problems (I.38) and (I.39)

The two problems in this subsection are the only ones in the book not solved by algebra, but by the rule of three. The enunciation to (I.38) is "ten pounds ( $\operatorname{art} \bar{a} l)$ cost nine dirhams. How many [pounds] cost two dirhams?"41, and (I.39) is "What is the value of three pounds?" given the same ratio. These are much like al-Khwārizmī's first two sample problems in his chapter on $m u^{c} \bar{a} m a l a \bar{t}$, translated above in Sect. 4. Problem (I.38) is translated in the Appendix.

With 39 problems, this section contains half the problems in the chapter. The most any other section has is twelve problems, those which simplify to an equation of the form $a x^{2}+b=c x$. In this section al-Sulamī has grouped his problems mainly by type, which yields a local seriality that his later sections lack.

The next section begins "Second section of this chapter, on problems that lead to $m \bar{a} l$ s equal roots". ${ }^{4}$ The nine problems are divided thus:

Problems (II.1) to (II.5) and (II.7) to (II.9)

These type [M] problems are characteristic of those we find in al-Khwārizmī especially, and also Abū Kāmil. They call for the multiplication of terms involving the $m \bar{a} l$, and sometimes also square roots. Problems (II.4) and (II.5) are the same as al-Khwārizmī's (11) and (32) respectively, and all but (II.7) is a small variation on some other problem in al-Khwārizmī. The equation in problem (II.8) is of the form $a x^{2}=b$, so this problem should really be in the next section. Problem (II.2) is translated in the Appendix.

\footnotetext{
40 [2], pp. 705.18-707.20.

${ }^{41}$ f. $57 \mathrm{~b} .14$.

42 f. 58 b. 1 .
} 


\section{SHS Web of Conferences}

Problem (II.6)

A problem about distributing money. (The word "māl" does not appear.)

Problem (II.9)

This is a type [10] problem, except that $\sqrt{20}$ is used instead of 10. It is otherwise the same as al-Khwārizmī's problem (T1).

The next section begins "Third section, on problems that lead to māls equal number". ${ }^{43}$ This section contains only six problems.

Problems (III.1), (III.2)

These type $[\mathrm{M}]$ problems are similar to problems in al-Khwārizmī.

Problems (III.3), (III.4), (III.6)

Type [10] problems (with (III.6) using $\sqrt{10}$ ), similar to problems in al-Khwārizmī.

Problem (III.5)

Two different $m \bar{a} l$ s add to twenty, and their product is 96 . This problem, including the solution, is taken from Diophantus' problem I.27, though it is not an exact translation. Also, it is stated as a type [M] problem rather than as type [10] (with 20 in place of 10). Ordinarily such a problem would have been posed in Arabic books as "Twenty: you divided it into two parts...". After 'Alī al-Sulamī finds the solution he solves the same problem with 100 in place of 96, this time getting irrational solutions. The first part of this problem is translated in the Appendix.

The next section begins "Fourth section, on problems that lead to $m \bar{a} l$ s and roots equal number". 44

Problems (IV.1), (IV.2), (IV.5), (IV.6)

These are type [M], again similar to the ones we find in al-Khwārizmī. Problem (IV.1), in fact, is the same as al-Khwārizmī's problem (T4).

Problem (IV.3)

A type [10] problem: one part divided by the other results in twice the other part.

Problem (IV.4)

Dividing a dirham among some people. This is the same as al-Khwārizmī's problem (28).

Problem (IV.7)

An army collects some booty. The enunciation is translated above in Sect.4. As noted, this problem is almost the same as Abū Kāmil's problem (44.1). ${ }^{45}$

The next section begins "Fifth section, on problems that lead to $m \bar{a} l \mathrm{~s}$ and number equal roots". ${ }^{46}$

Problems (V.1) to (V.8) and (V.12)

These are type [10] problems, taken from al-Khwārizmī or Abū Kāmil. It is easiest to show the sources in a table, revealing a bit of historical seriality:

\footnotetext{
43 f. $63 \mathrm{a} .10$.

44 f. $66 \mathrm{~b} .8$.

45 [2], p. 683.5.

46 f. 71 a. 4 .
} 
Les séries de problèmes, un genre au carrefour des cultures

$\begin{array}{cccc}\frac{\text { al-Sulamīinn }}{(V .1)} & \frac{\text { al-Khwārizmī }}{(T 5)} & & \text { Abū Kāmil } \\ \text { (V.2) } & (3) & \\ \text { (V.3) } & \approx(10) & \approx(35) \\ \text { (V.4) } & \approx(4) & (2) \\ \text { (V.5) } & & (19) \\ \text { (V.6) } & & (21) \\ \text { (V.7) } & & (22) \\ \text { (V.8) } & & (23) \\ \text { (V.12) } & (9) & \approx(T 4)\end{array}$

Problem (V.4) is the often-repeated reciprocals problem in which each part is divided by the other and the sum of the reciprocals is $4 \frac{1}{4}$. This is the only problem in the book that gets two different solutions (unless we count also problem (III.6), where a variation on the problem is also solved). First is the standard solution in which the parts are named "a thing" and "ten less a thing". In the second solution, announced with "and the second way", is the same as Abū Kāmil's fourth solution. The result of dividing "ten less a thing" by "a thing" is named "a dinar", and the equation is set up as "... fifty-two dirhams and a half less ten dinars and less five things and a fourth of a thing. So that equals a thing." 47 This eventually reduces to the simplified equation "a $m \bar{a} l$ and sixteen dirhams equals ten things", ${ }^{48}$ which happens also to be the right type for this section.

Problems (V.9), (V.10)

Problems about a postman overtaking another who had a head start. These are the same as the first and third of Abū Kāmil's problems of the same type. ${ }^{49}$

Problem (V.11), announced with "Another type".

The problem is about money.

The next section begins "Sixth section, on problems that lead to roots and number equals $m \bar{a} l \mathrm{~s}$ ". ${ }^{50}$

Problems (VI.1) to (VI.3)

Three type [M] problems. Problem (VI.1) is al-Khwārizmī’s (23).

Problem (VI.4)

This is a problem of dividing an amount of money among some men, but this time it is a $m \bar{a} l$ less two of its square roots that is divided.

Problems (VI.5)

Two men want to buy something (a horse, maybe?). Similar to problem (I.36).

\section{Assessment}

Recall the three questions I posed at the beginning of this article: First, what can we say about the order of the problems? Second, what are the sources from which the author borrowed? And third, how does al-Sulamī's book compare with the books of the other algebraists?

The first question is about seriality. After their first six problems al-Khwārizmī and Abū Kāmil show little overall attention to the ordering of their problems, and indeed what little seriality we see may be historical rather than deliberate. 'Alī al-Sulamī, by contrast, gave careful consideration to the ordering

\footnotetext{
47 f. 74 b. 5 .

48 f. 75 a. 13 .

49 Problems (45.1) and (45.2) in [2], pp. 691, 693.

50 f. 83 a.6.
} 
of his problems, both globally, with one section for each of the six canonical equations, and locally, by arranging problems within each section more or less by type. His is the earliest collection in Arabic that I know with such a tight structure. That he was concerned with his problems is even evident in the second part of the title of his book, "... and What One Can Learn from Its Examples [i.e. problems]".

To make his global scheme work, al-Sulamī omitted solutions by "arithmetical reasoning" and with one exception he restricted himself to a single algebraic solution to each problem. That way he could classify the problems according to the type of simplified equation in the solution. But he changed the ordering of the equations that he had given in his first chapter. Now problems whose equations simplify to the type $b x=c$ come first. This was a deliberate choice, and I suspect that it served a pedagogical purpose. This type of equation is the simplest, so these problems would be easiest to solve by algebra. They are also the ones that can be solved by other methods like single false position, double false position, and working backwards. In fact, problems like al-Sulamī's (I.1) to (I.4) are typically solved by these methods in later arithmetic books

Al-Sulamī gives a local ordering to his problems in the first section based on problem type. Problems (I.1) to (I.4) are type [M], and (I.5) to (I.8) are type [10]. After this the groups are announced with bold letters: "On calculating a wage" for problems (I.12) to (I.22) ; "Another type, on a payment" for problem (I.23), "Another type, on reservoirs" for (I.24) and (I.25), "Another type" for problems (I.26) to (I.35), and "Another type, on encounters" for (I.36) and (I.37).

The last type in this section is called "another type, on calculating business transactions". But he does not solve these problems by algebra. Instead, he explains the rule of three and gives two problems, (I.39) and (I.39), illustrating the method. Al-Khwārizmī had given a separate chapter for the rule of three after his algebra proper, but al-Sulamī brings it into his main collection.

The remaining five sections do not contain enough problems to warrant subheadings. The only subheading after the first section is "Another type" before problem (V.11). In these sections two clusters of problems seem to be grouped by type: (II.1)-(II.8), and (V.1)-(V.8), but especially in the second case the grouping appears to be historical rather than deliberate. Sometimes another type sneaks into a group, like problem (I.33) in the group (I.26)-(I.35), and problem (II.6) in the group (II.1)-(II.8). Then occasionally a stray problem will be separated from problems of its own type, like problem (V.12), which would have fit well with (V.1)-(V.8).

For the second question, we can identify four different sources for 'Alī al-Sulamī's problems: the algebra books of (1) al-Khwārizmī and (2) Abū Kāmil, (3) some problem collections from arithmetic, either from some lost book(s) or from an oral tradition, and (4) Diophantus' Arithmetica. The presence of the problem of Diophantus is curious not just because there is only one, but also because 'Ali alSulamī's nine indeterminate problems (I.26)-(I.32), (I.34), and (I.35) are not from the Arithmetica, at least from the books that survive. They are not taken from Abū Kāmil's 38 indeterminate problems, either, though they are stated with the same kind of language. They seem to be drawn from the same oral tradition from which Abū Kāmil drew.

To address the third question, the most striking differences are that al-Sulamī's book is better organized than the other three, and he does not give any proofs. With regard to the problems, recall that al-Khwārizmī's and Abū Kāmil's "algebra proper" both consist of the abstract type [M] and type [10] problems, with a small number of problems on dividing dirhams among some men. Both authors treat other types of problems in later chapters or books that al-Sulamī would incorporate into his "algebra proper": al-Khwārizmī's chapter on business transactions, and Abū Kāmil's indeterminate problems and problems posed in practical terms, like the distribution of booty or the price of a horse, in book III. A total of 28 of al-Sulamī's 78 problems are of such practical types.

'Alī al-Sulamī does not let his borrowings interfere with the seriality of his problems. We do not see him copying several problems from any one book without regard to how they fit in his overall scheme. He manages to link algebra with elementary practical arithmetic through his selection and ordering of problems. His book is a thus good introduction to algebra for anyone already familiar with arithmetic. 


\section{Appendix}

Here are translations of some of al-Sulamì's problems.

Problem (1.1).

A $m \bar{a} l$, if you added to it two-thirds of it, it brought back ten dirhams.

So make your $m \bar{a} l$ a thing, and add to it its two-thirds, to get a thing and two thirds of a thing. So this equals ten $\left[1 \frac{2}{3} x=10\right]$. The desired $[m \bar{a} l]$ is what equals the thing. Because you made the $m \bar{a} l$ a thing, and the thing with respect to one and two-thirds is its three-fifths, then three-fifths of the ten, which is six, equal the thing, which is the $m \bar{a} l$.

Here the unknown $m \bar{a} l$ ("quantity") is named "a thing" at the beginning of the solution, and the equation "a thing and two thirds of a thing. . .equals ten" is set up and solved.

Problem (I.28) is a characteristic example of an indeterminate problem.

A $m \bar{a} l$ : it has a root. If you added to it a dirham, then the sum has a root.

So make your $m \bar{a} l$ a $m \bar{a} l,{ }^{51}$ and add to it a dirham, and make its root a thing and a third of a dirham. ${ }^{52}$ And multiply that by itself to get: a $m \bar{a} l$ and two thirds of a thing and a ninth of a dirham equals a $m \bar{a} l$ and a dirham $\left[x^{2}+\frac{2}{3} x+\frac{1}{9}=x^{2}+1\right]$.

Then cast away a $m \bar{a} l$ by a $m \bar{a} l$ and a ninth of a dirham by a ninth of a dirham, leaving: eight ninths equals two thirds of a thing $\left[\frac{8}{9}=\frac{2}{3} x\right]$. So the thing is one and a third, which is the root of the māll.

Problem (I.38), solved by the rule of three.

Ten pounds ( $\operatorname{art} \bar{a} l)$ cost nine dirhams. How many pounds cost two dirhams?

So the two dirhams are the first number, and the nine is the second number, and what you get for two dirhams is the third, which is the unknown, and the ten is the fourth. And the first quantity with respect to the second is as the unknown quantity with respect to the fourth. So you multiply the first, which is two, by the fourth, which is ten, to get twenty. And you divide that by the second, which is nine, resulting in two and two ninths, which is the unknown third.

In the rule of three one has a proportion between four numbers, first : second :: third : fourth. In this problem the third is the unknown, so its value is found by multiplying the first by the fourth, then dividing the result by the second. Because no unknown is named and no equation is set up, this is not a solution by algebra.

\section{Problem (II.2).}

So if [someone] said, a $m \bar{a} l$ : cast away from it its third, then multiply the remainder by itself, so it brought back the $m \bar{a} l$.

So make your $m \bar{a} l$ a thing, and cast away from it its third, leaving two thirds of a thing. Multiply that by itself, to get four ninths of a $m \bar{a} l$ equals a thing $\left[\frac{4}{9} x^{2}=x\right]$.

So complete the $m \bar{a} l$, by which you multiply everything you have by two and a fourth, to get: a $m \bar{a} l$ equals two things and a fourth $\left[x^{2}=2 \frac{1}{4} x\right]$. So the $m \bar{a} l$ is two and a fourth, which is the unknown. ${ }^{53}$

\footnotetext{
51 I.e., name the $m \bar{a} l$ (quantity) a $m \bar{a} l\left(x^{2}\right)$.

52 I.e., let $\sqrt{x^{2}+1}$ be $x+\frac{1}{3}$.

53 f. 58 b. 14 .
} 
Problem (III.5), with the product of 96. This is taken from Diophantus' Arithmetica I.27.

So if [someone] said, two different $m \bar{a} l$ s. If you added them it gave twenty, and if you multiplied one of them by the other it yielded ninety-six.

So make one of the parts ten and a thing and the other ten less a thing, so their sum is twenty. Then multiply ten and a thing by ten less ${ }^{54}$ a thing to get a hundred dirhams less a $m \bar{a} l$ equals ninety-six. So restore ${ }^{55}$ the hundred by the $m \bar{a} l$ and add it to ninety-six. And cast away ninety-six by its same, leaving a $m \bar{a} l$ equals four. And its root is two, which is the thing. So you add it to ten to get twelve, and the other $[m \bar{a} l]$ is eight.

\section{References}

[1] Abū Kāmil, The Book of Algebra: Kitāb fì al-jabr wa'l-muqābala Edited by Jan P. Hogendijk (Institute for the History of Arabic-Islamic Science at the Johann Wolfgang Goethe University, Frankfurt am Main, 1986).

[2] Abū Kāmil, Algèbre et Analyse Diophantienne. Édition, traduction et commentaire par Roshdi Rashed (De Gruyter, Berlin, 2012).

[3] Anbouba, Adel. «L'algèbre arabe aux $\mathrm{IX}^{\mathrm{e}}$ et $\mathrm{X}^{\mathrm{e}}$ siècles. Aperçu général ». Journal for the History of Arabic Science 2, 66-100 (1978).

[4] al-Khwārizmī, Le Commencement de l'Algèbre. Texte établi, traduit et commenté par Roshdi Rashed (Blanchard, Paris, 2007).

[5] al-Khwārizmī, The Beginnings of Algebra. Edited, with translation and commentary by Roshdi Rashed (SAQI, London, 2009). An English translation of [4].

[6] Oaks, Jeffrey A. "Equations and equating in arabic mathematics". Archives Internationales d'Histoire des Sciences 60, 265-298 (2010).

[7] Oaks, Jeffrey A. "Al-Khwārizmī's worked-out problems". HASTEC's Carnet de Recherche, http://problemata.hypotheses.org/157 (2012).

[8] Oaks, Jeffrey A. "The series of problems in al-Khwārizmī's Algebra". HASTEC's Carnet de Recherche, http://problemata.hypotheses.org/157 (2012). A Greek translation appears in Neusis 22, 149-167 (2014).

[9] Oaks, Jeffrey A. and Haitham Alkhateeb. "Māl, enunciations, and the prehistory of Arabic algebra". Historia Mathematica 32, 400-425 (2005).

[10] Rashed, Roshdi “L'idée de l'algèbre selon al-Khwārizmī”. Fundamenta Scientiae 4, 87-100 (1983).

[11] Rosenfeld, Boris A. and Ekmeleddin Ihsanoğlu, Mathematicians, Astronomers, and Other Scholars of Islamic Civilisation and Their Works (7th-19th c.) (Research Centre for Islamic History Art and Culture (IRCICA), Istanbul, 2003).

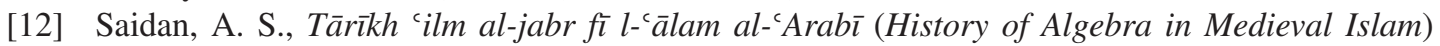
(al-Majlis al-Wațan̄i lil-Thaqāah wa'l-Funūn wa'l-Ādāb, Qism al-Turāth al-`Arabī, Kuwait, 1986).

\footnotetext{
54 The text says "and".

55 The text has $\bar{a}-h-r$, which is visually close to ajbir ("restore").
} 